\title{
The Formalists' Heritage in Literature Teaching Methodology
}

\author{
Boris A. Lanin* \\ Institute for Strategy of Education Development \\ of the Russian Academy of Education \\ 5/16 Makarenko Str., Moscow, 105062, Russia
}

Received 10.01.2017, received in revised form 18.03.2017, accepted 22.04.2017

The formalists' ideas have been mentioned neither in the textbooks nor in the teachers' guidelines though they influenced the whole system of literary education. They became an implicit motto of scholar analysis. Although official education cursed "the formalism" as the heresy that confronted "Marxist methodology", many formalists' tools and methods were widely used. In the 1920s their most prominent representatives were I.P. Plotnikov. M.I. Rybnikova, and later-M.G. Kachurin, G.I. Belen'kii and G.G. Granik, who developed that line in the secondary school textbooks. So, the core essence of phenomena survived and still influences school literature as a discipline.

Keywords: formalists, OPOJAZ, methods of teaching literature, ostranenie (estrangement), school textbooks.

This article was supported by Russian Foundation for Fundamental Research (grant № №16-06-00963 (a).

DOI: 10.17516/1997-1370-0081.

Research area: philology.

In 2012, in Tokyo, there was published a Japanese book on the Russian formal school (Kaizawa et al., 2012). It had 10 chapters written by famous professors - literary critics. This serious and profound study is evidence of the Russian formal school authority in the development of humanitarian thinking. The strange anniversary of the strange word "ostranenie" (estrangement) was approaching. A hundred years ago Viktor Shklovsky published a small scholarly work where this word appeared for the first time ever. Few people understood its meaning at the beginning, but it was destined long life. It was heard in all languages, in which only literary studies were possible: ostrAnenie (meaning "estrangement"). The stress was supposed to be done on the second syllable. In 1916-1919 there were collected and published collections on the theory of poetic language. These three small books (together with the book "Resurrection of the Word" published by V.B. Shklovsky in 1914) marked the birth of a new society - the Society for the Study of Poetic Language, or OPOJAZ. The Society for the Study of Poetic Language was primarily a community of colleagues and not always like-minded people. There was a great hope for them to understand

(C) Siberian Federal University. All rights reserved

* Corresponding author E-mail address: laninb@yandex.ru 
what literary fiction is, what its mystery is, and what its secret is. At first the emphasis was made on the features of the poetic language and the poetic word.

A hundred years later, in 2016, a fundamental three-volume anthology "The Formal Method: an Anthology of Russian Modernism" by S. Ushakin was published. In the first volume "Systems" (Ushakin, 2016, Vol. 1) there were published program articles, or "manifestos", organized as "Device (Shklovsky) - Conflict (Eisenstein) Parody (Tynyanov) - Pointlessness (Malevich) Tectonics (Gan)"; in the second volume "Materials" (Ibid, Vol. 2) there were published "Kinoveshch' (Dziga Vertov) - Fact (Tretyakov) Literary Daily Life (Eikhenbaum) - Perspective (Rodchenko) - Texture (Stepanova)"; in the third volume "Technology" (Ibid, Vol. 3) there were printed "Reversibility (El Lissitzky) - Shifts (Jacobson) - Conventionality (Meyerhold) Repetitions (Brik) - Organic Nature (Tatlin)". The three-volume book is destined to become an irreplaceable collection for philologists and other scholars for many years to come.

The formalists noticed the "petrification" of the word, its "necrosis", drew attention to the fact that the "sensibility" of the word was lost. Therefore, V.B. Shklovsky called his early book "Resurrection of the Word", wishing to emphasize the idea of returning a fresh, non-trivial sound to the word. V.B. Shklovsky embodied this idea in the concept of "estrangement". Here was a connection with the futurists' fixation with the "self-valuable word".

OPOJAZ is one of the most striking branches of the formal school in Russian literary criticism. They faced an exacting task: "To revive the poetics" (Eikhenbaum, 1987: 378), and for this it was necessary "... to reject philosophical prerequisites, psychological and aesthetic interpretations, etc. The break with philosophical aesthetics and with ideological art theories was dictated by the very state of things. It was essential to turn to facts and, moving away from common systems and problems, start from the middle, from the point where the art fact finds us" (Ibid, p. 379).

The society grew out of the Pushkin Seminary led by Professor S.A. Vengerov. He was visited by Shklovsky, Tynyanov and Balukhaty. The level of mutual demand in the Vengerov's Seminary was unusually high.

At different times OPOJAZ united such well-known philologists as E. Polivanov, R. Jacobson, L. Yakubinsky, O. Brik, V. Zhirmunsky, Y. Tynyanov, B. Eikhenbaum, V. Shklovsky. But the scientists who were part of the OPOJAZ were "too personal", and the aegis of any community could not become a common denominator for them. They were quite different among themselves. Here is how Yury Tynyanov outlined this difference: "Victor is a mechanic... He believes in construction (said about Viktor Shklovsky), he thinks he knows how a car is made... And I, I am a determinist. I feel life spilling over me. I feel as if history makes me" (Kaverin, 1966: 90).

"Construction", certainly. This gave the formal school that "brilliant one-sidedness", which W. Erlikh (Erlikh, 1996) marked while he was writing about formal school in his wellknown book. "Once I came up with the term 'ostranenie'. Argued about it with Eikhenbaum", Victor Shklovsky remembered decades later. "He proposed to replace it with 'oproshchenie'2 I did not agree" (Jacobson, 1987: 275).

Viktor Shklovsky, a Cavalier of the St. George Cross, former assistant to the military commissar of the Provisional Government, a participant in the anti-Bolshevik SocialistRevolutionary conspiracy, who left Russia, wary of imminent arrest, on the ice of the Gulf of Finland, making his wife hostage, took over the brilliant formalist philologist, one of the 
founders of the OPOJAZ. Alas, one of the first formalists, Viktor Shklovsky, the first of them (again the first...) issued a penitential article "The Monument to Scientific Mistake", in which he admitted his own methodological "mistakes" and spoke of the insufficiency of this method in comparison with the "Marxist" one. Shklovsky repented for a long time. Even in 1970, after 30 years, Shklovsky continued to repent, saying, if before he "recklessly said that the work is 'the sum of devices', now I think that literature is a "system of systems" (Shklovsky, 1970: 232). And yet the opposition of the material to the device, not only a sharp but well-argued opposition, became one of the most fruitful ideas in literary criticism of our century, by the way, in due time it was not fully appreciated by the teaching literature methodologists, for whom the main opposition was "form/content".

Obviously, the formula "The content of an artwork is exhausted by the sum of its stylistic devices" was deliberately polemical. When this formula was implemented in literary criticism, it certainly acquired a wider application, embracing traditional categories as well.

The usage of a new methodology seemed to be very promising in the analysis of the plot, a category that was previously considered a category of content. In 1918, Shklovsky began working on the article "The Relationship between Devices of Plot Construction and General Devices of Style". He contrasted the plot and the storyline, and thus embodied one of the main oppositions "material/ device" in a more concrete and visual one: "plot/ fabula". Further development of these ideas was given in the book "The Plot as a Phenomenon of Style".

Following Shklovsky, many formalists believed that to understand how "the thing is made, constructed" means to find those universal criteria using which any work could be evaluated. Shklovsky also believed or pretended that he believed that he knew the real, right "rules" on which literary works were molded. When Shklovsky wrote that Yuri Olesha's "Envy" was "wrongly made", he thereby exposed himself to some extent: literature is always "wrong", rightness in literature is tantamount to a template, rather than a "device". He was at odds with himself, because for Shklovsky, too, the main device was "estrangement", the transformation of a thing into something new under the unorganized, nontrivial, "strange" view of the literary hero behind whom the artist stands.

Shklovsky alone wrote about 70 books during his life. He left us magnificent memoirs "Sentimental Journey", "Once upon a Time", etc. Finally, Shklovsky wrote one of the best novels of the $20^{\text {th }}$ century - "Zoo". His restless talent sought application and implementation in various fields...

In 1924-1926 Y. Tynyanov and B. Eikhenbaum conducted a seminar entitled "Russian Prose" in the State Institute of Art History. The book of the same name summarized the scientific results of this important attempt to apply the formal method strictly and consistently. The book "Russian Prose" (1926) did not include V. Shklovsky's works. A new, second wave of formalists terminated the existence of the bright direction. The point is most likely that "their student diligence played an instructive trick on them, and on their adopted concepts. It turned out that looking into narrow, specific applications of the "formal method" clearly revealed its weak points. The most vulnerable was its claim to the totality, which the young people took too seriously. The pluralism, which Eikhenbaum insisted on so persistently and convincingly, remained a declaration only..." (Levchenko, 2007: 248).

Today, scientists write that in the formalism poetics "the most important function of a device is to serve estrangement $<\ldots>$ Estrangement is a 
vision of an object in some unusual perspective. Thanks to it, art overcomes the automated, i.e. passive-mechanical, abstract-algebraic perception of surrounding people and objects. A pair of concepts (automation and estrangement) introduced by V. Shklovsky apply not only to the field of art, but also to the psychology of perception. In everyday life, Shklovsky thought, we recognize objects, but do not see them..." (Khalizev et al., 2015: 59). Moreover, the literary (or from literary studies?) device is clearly enlarged to the scale of the philosophical category, for "through estranging devices people should have a sense of life returned". Shklovsky was convinced that art exists for this. In order to fulfill its high saving role, it does not need any meanings" (Ibid, 59-60). In the fundamental work devoted to the history and the present state of Russian philology, K.E. Shtain and D.I. Petrenko explained: "The OPOJAZ theoretical guidelines are marked by a polemic attitude towards the eclecticism of pre-revolutionary academic science and at the same time the strengthening influence of the aesthetic principles of acmeism, futurism, and subsequently - structuralism. The objective was the synchronous sections in the literary process description, the technical methods that can be "accurately" studied. The research was based on V.B. Shklovsky "estrangement" theory connected with the factor of unusualness in the work system. Such are literary and artistic techniques (their combination), used by the artist or the literary trend. When the action of some devices is weakened, they become a cliché followed by a need for new techniques, and then one literary system is replaced by another. Applying a comparative typological method, new linguistic ideas, statistical methods of study, OPOJAZ accumulated a number of observations especially valuable for philology. The question was posed about the systemic nature and the internal regularities concerning the correlation of elements and their evolution within a single cultural series, this was rather fruitful and made it possible to use linguistic methodology in the system of other cultural series (cinema, painting, music, etc.) (Shtain, Petrenko, 2011: 92).

The fruitfulness of the idea manifests itself not only in the longevity of its traditions, but also in the possibility of transferring ideas to related disciplines. When for the first time I was working on the anthology of Russian teaching and studying literature methodology (Sapporo, 2001), it became obvious to me that in its development during the Soviet and post-Soviet period that the concept of "estrangement" played a decisive role in it. Of course, it was necessary for Soviet methodologists to swear by "national" and "party spirit". However, when it came to analyzing the literary text, "estrangement", though not called by its name and thus not mentioned, was inevitable. Formalism and formal school in the official school methodology were considered unacceptable, but methods and techniques were widely used. In the 1920s they were accepted literally by all methodical schools. Their direct representative in the school methodology was I. Plotnikov, though he understood at what time he was living and was ready for compromises. In the 1920s Plotnikov proposed: "The healthy harmonization of sociological and formal methods, with the former studying the historical genesis of the work, and the latter - the work itself, is the most appropriate solution..." (Plotnikov, 1924: 35).

Even the psychoanalytic school (methodological followers of Professor I.I. Ermakov) drew attention to the analysis of student errors in the literature perception. In fact, they compared the undisclosed "estrangement" with the "right" and "biased reality perception". These approaches were popularized by M.A. Rybnikova in the mid-1920s. They actually gave rise to her book "On the composition" (1924), which soon became a classic methodical work, 
as, after all, in fact, it was devoted to the problem of "how the literary work is done".

"Estrangement" and correspondent approaches became formally legalized after the doctoral dissertation of G.I. Belen'kii "Theory of literature in school" (1975). Sincerely paying tribute to ideological categories, and sometimes even praising them, G.I. Belen'kii cultivated a taste for the heritage of the formal school. This is an important merit of his technique. "Estrangement" as a device was often used by G.I. Belen'kii both in his school textbook for the $8^{\text {th }}$ grade, the only one published during the Soviet era, and in the series of textbooks which he edited and which were published in the postSoviet era.

His methodological opponents such as followers of Academician G.G. Granik (G.G. Granik, L. Kontsevaia and S. Bondarenko, who has just passed away, were working on "The problems of creating school textbooks" at the Institute of Psychology of the Russian Academy of Education) also turned to the phenomenon of estrangement, but they did not call it by its name again! They called for the analysis of works based on "unusual", "unhabituated" words, as they form the very beginning of any school literary analysis. Speaking about studying the Russian language and literature in the school, G.G. Granik asserts: "in both courses first of all the word is studied. And then the analysis is wider, concerning speech, text. This should be the basis for their rapprochement. Yet, we must not forget that the word in direct meaning in everyday live speech and the word in a work of art are different words" (Granik, 2007: 19).

Finally, this technique is widely used in our textbooks, which we have created in RAE with V.M. Shamchikova and L.Iu. Ustinova, and which are included in the Federal list of textbooks for general secondary schools. Everywhere, where methodologists and teachers reveal new meanings of the word, making it "strange", the ideas of the Russian formal school continue living.

cinema-object
simplification

\section{References}

Eikhenbaum, B.M. (1987). Teoriia "formal'nogo metoda" [The "formal method" theory], In O literature [On literature]. Moscow.

Erlikh, W. (1996). Russkii formalism: istoriia i teoriia [Russian formalism: history and theory]. St. Petersburg.

Granik, G.G. (2007). Psikhologo-didakticheskaia kontseptsiia uchebnikov novogo tipa po russkoi filologii [Psychological and didactic concept of new type Russian philology textbooks], In Psikhologodidakticheskie osnovy sozdaniia uchebnikov novogo tipa po russkoi filologii [Psycological and didactic bases of creation of new type Russian philology textbooks, ed. by G.G. Granik]. Moscow.

Jacobson, R. (1987). Raboty po poetike [Works on poetics]. Moscow.

Khalizev, V.E., Kholikov, A.A., Nikandrova, O.V. (2015). Russkoe akademicheskoe literaturovedenie: istoriia i metodologiia (1900-1960-e gody) [Russian academic literary criticism: history and methodology (1900-1960s)]. Moscow, St. Petersburg.

Kaverin, V. (ed.) (1966). Yury Tynyanov. Pisatel' i uchenyi. Vospominania. Razmyshleniia. Vstrechi [Yury Tynyanov. Writer and scientist. Memories. Reflections. Meetings]. Moscow.

Kaizawa, H., Nonaka, S., Nakamura., T. (eds.). (2012). Vozvrashchaias' $k$ russkomu formalizmu: iazyk, media,poznanie[ReturningtoRussianformalism: language, media, cognition]. Tokyo(InJapanese). 
Levchenko, Ia. (2007). Shkola, kotoroi ne bylo [The school that did not exist], In Levchenko, Ia. (comp.) "Mladoformalisty”: Russkaia proza ["Young formalists: Russian prose]. St. Petersburg.

Plotnikov, I.P. (1924). Revoliutsionnaia literature [Revolutionary literature]. Moscow.

Shklovsky, V.B. (1970). Tetiva: O skhodstve neskhodnogo [Bowstring: On the similarity of dissimilarity]. Moscow.

Shtain, K.E., Petrenko, D.I. (2011). Filologiia: Istoriia. Metodologiia. Sovremennye problemy [Philology: History. Methodology. Modern problems]. Stavropol.

Ushakin, S. (ed.) (2016). Formal'nyi metod. Antologiia russkogo modernizma. T. 1. Sistemy [The formal method. Anthology of Russian Modernism. Vol. 1. Systems]. Yekaterinburg.

Ushakin, S. (ed.) (2016). Formal'nyi metod. Antologiia russkogo modernizma. T. 2. Materialy [The formal method. Anthology of Russian Modernism. Vol. 2. Materials]. Yekaterinburg.

Ushakin, S. (ed.) (2016). Formal'nyi metod. Antologiia russkogo modernizma. T. 1. Tekhnologii [The formal method. Anthology of Russian Modernism. Vol. 3. Technologies]. Yekaterinburg.

\title{
Наследие формалистов в методике преподавания литературы
}

\author{
Б.А. Ланин \\ Институт стратегии развития образования \\ Российской академии образования \\ Россия, 105062, Москва, ул. Макаренко 5/16
}

\begin{abstract}
Идеи формальной школь широко использовались в методике преподавания литературы. При этом главные термины, например «остранение», обычно не назывались. Наследие формалистов воздействовало имплицитно. Хотя многие методисты советской поры вынуждены были использовать марксистскую риторику, к приемам и приниипам формалистов они прибегали регулярно (даже проклиная их). В 20-е годы формальный метод перенес в риторику И.П. Плотников, затем - М.И. Рьбникова, позже - М.Г. Качурин, Г.И. Беленький и Г.Г. Граник. Достижения формалистов используют и новейшие учебники, развивая литературу как школьную дисииплину.
\end{abstract}

Ключевые слова: формалисть, ОПОЯЗ, методика преподавания литературы, остранение, икольные учебники.

Работа выполнена в рамках гранта РГНФ № 16-06-00963 (a) «Национальный читательский канон: психолого-педагогические основания».

Научная специальность: 10.00.00 - филологические науки. 